\title{
17 Population Ageing, Domestic Consumption and Future Economic Growth in China
}

Yang Du and Meiyan Wang

\section{Introduction}

In the newly released Twelfth Five-Year Plan (2011-15), increasing the role of domestic demand as a driver of economic growth is identified as one of China's major priorities in the years ahead. According to the most recent statistics from the National Bureau of Statistics (NBS), final consumption accounted for 48 per cent of gross domestic product (GDP) in 2009, which included 35 percentage points from household consumption. In most industrialised countries, consumption accounts for more than two-thirds of GDP, and the share of government consumption in final consumption is not as high as in China either. Given that the Chinese Government has already had in place for many years the specific goal of raising household consumption, it seems clear that this is neither an easy task nor one that can be accomplished in the short term.

More seriously, as a middle-income country, China has already entered a period of population ageing. According to the Sixth Population Census, conducted in 2010 (NBS 2011), people aged sixty and above accounted for 13 per cent of the total population, while the share of people aged sixty-five and above was 9 per cent. Compared with the Fifth Census, the above two shares increased 3 and 2 percentage points, respectively. This has placed China in a uniquely challenging position - with the process of ageing occurring far earlier in its development than has been the experience in the industrialised world.

In addition to the insufficient resources for supporting the elderly and a pension system that is still under construction, one of the major concerns about the impact of ageing on development is that elderly people tend to consume less, which is of particular relevance in China - a country eagerly seeking to rebalance its economy towards domestic consumption.

The spending habits of people at different ages during the life cycle have been a topic of great interest in analyses of macroeconomic stability and economic policy for a long time. Dating back to Modigliani and Brumberg's (1954) life-cycle model, the consumption-saving choice by households is a key element in determining inter-temporal consumption patterns so as to smooth consumption over the life cycle (Browning and Lusardi 1996).

Many recent studies have been motivated by the observed reduction in consumption following retirement, giving rise to the so-called retirement consumption puzzle that has been empirically observed in many industrialised economies (Banks et al. 1998; Bernheim et al. 1997). In his review paper, Hurst (2008) summarises five stylised facts that have emerged from the recent literature on consumption behaviour during retirement, including declines in spending on food and work-related expenses, constant or increased spending 
on non-durables, and substantial heterogeneity across households. Overall, he thinks that the life-cycle model does well in explaining the consumption pattern of most households, including the pattern of aged consumption.

The determination of consumption choices over the life cycle is more complicated in a developing and transitioning country such as China-compared with industrialised countries - even without taking into account the question of ageing. For example, to a large extent, the consumption behaviour of the elderly is determined by how the pension system is arranged - wherever those elderly are. Yet the Chinese case is complicated by the significant changes in the elderly support system. Prior to the reform initiated at the end of the 1970s, urban residents enjoyed comprehensive welfare treatments attached to their employers. The urban economic restructuring in the 1990s, however, has brought about challenges to the elderly support system. To deal with massive labour-market dislocations, the Chinese Government adopted a combination of individual accounts and social pooling as the uniform pension system in 1997. In spite of the shortage of funds in the pension system, the individuals who are eligible in the system are well protected since pension social provisions were implemented in 1998. Those elderly who are not supported by current programs, however, will find it difficult to deal with poverty and negative shocks. These two mixed groups of elderly people are likely to have substantial heterogeneity in expenditure when facing ageing simultaneously.

Other types of social security and public services also affect consumption patterns. For example, when encountering health shocks, people who are outside the healthcare system or can get only limited benefits from the healthcare system have to bear high out-of-pocket medical costs and in turn reduce their spending on other items. Huge burdens in education expenditure might cause intergenerational transfers from older to younger generations. For these and other reasons, the determinants of age-specific consumption patterns in an ageing society are of policy importance. While these problems are not entirely unique to China, they are perhaps more prominent there than elsewhere, particularly in an era of transitioning health and educational systems.

In spite of the policy relevance to long-term economic growth and macroeconomic fluctuations of the consumption patterns of elderly households, the empirical work on this is scant in China. This chapter employs data from an urban household survey conducted by the Institute of Population and Labour Economics at the Chinese Academy of Social Sciences in 2010. The China Urban Labour Survey (CULS) was implemented in five cities: Shanghai, Wuhan, Shenyang, Xian and Fuzhou. The first two rounds were conducted in 2001 and 2005 respectively. In each city, 700 local-resident households and 600 migrant households were surveyed. For the purpose of this study, only the local-resident sample is used. The survey provides information at both the household and the individual level.

This chapter is organised as follows. The next section briefly introduces the features of demographic transition in China and the process of population ageing. Then we employ the survey data to describe the pattern of consumption in China. This is followed by a presentation of the results from an empirical model that seeks to explain the relationship between population ageing and consumption. The final section concludes with some relevant policy recommendations. 


\section{Population Ageing in China}

China completed the process of demographic transition in the past century. In fact, the total fertility rate in China has been declining since the 1970s. This process was driven first by the decline in mortality rates before the 1970s, and then by strict population policies in the 1980s and fast economic development since the country's period of opening up. With a low fertility level for decades, China has long been a country facing an ageing society. As Figure 17.1 depicts, in 2010, people aged sixty-five and above accounted for 8.9 per cent of the total population and the old-age dependency ratio reached 11.9 per cent in the same year. According to the widely accepted definition, China has already become an ageing society. The features of ageing are rooted in the process of demographic transition. The following aspects of demographic transition and ageing in China are of relevance to this chapter.

Figure 17.1 Share of the elderly and old-age dependency in years with a census

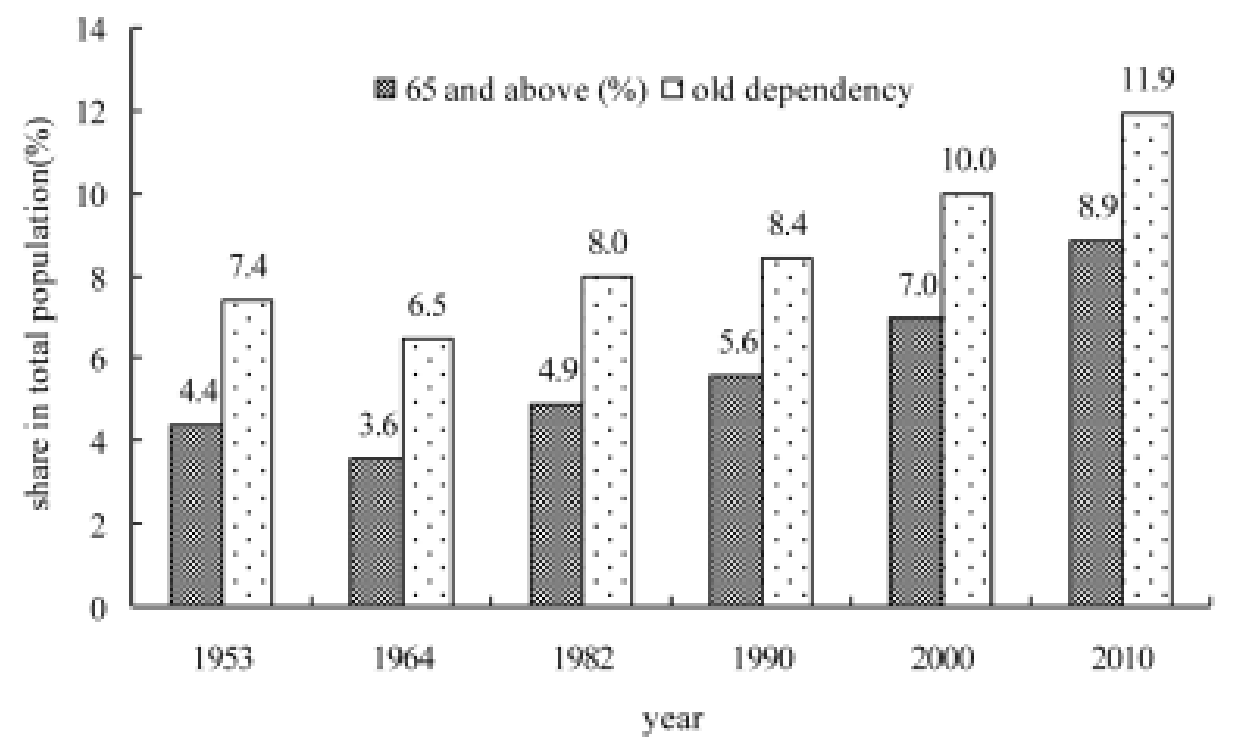

Sources: Data for 2010 are from NBS (2011); data for the other years are from NBS (various years).

First, China has experienced a relatively rapid process of population ageing compared with many other economies. As seen in Figure 17.1, between 1982 and 1990, the share of elderly people (aged sixty-five and above) increased by 0.7 percentage points, compared with an increase of 3.3 percentage points during the two decades since then. In the big cities we surveyed, the situation is even more serious. For example, in Shanghai, people aged sixty and above accounted for 23.4 per cent of its population in 2011, with people aged sixty-five and above accounting for 16 per cent of the total population.

To compare this process across economies, demographers use the duration and the multiplier of transition. The former refers to the time interval from the start of the first stage of transition to the end of the third stage of transition and the latter refers to the ratio of the population at the end of the transition to the start of the transition, which 
essentially indicates transition speed. China is exceptional in both of these terms, as shown in Table 17.1, due to the combination of strict population policies and rapid economic development, both of which accelerated the transition.

Table 17.1 The features of demographic transition in selected economies

\begin{tabular}{|l|c|c|c|}
\hline & $\begin{array}{c}\text { Start and end of } \\
\text { transition }\end{array}$ & Duration (years) & Transition multipliers \\
\hline Sweden & $1810-1960$ & 150 & 3.83 \\
\hline Germany & $1876-1965$ & 90 & 2.11 \\
\hline Italy & $1876-1965$ & 90 & 2.26 \\
\hline Former Soviet Union & $1896-1965$ & 70 & 2.05 \\
\hline France & $1785-1970$ & 185 & 1.62 \\
\hline China & $1930-2000$ & 70 & 2.46 \\
\hline Taiwan, China & $1920-1990$ & 70 & 4.35 \\
\hline Mexico & $1920-2000$ & 80 & 7.02 \\
\hline
\end{tabular}

Source: Peking University Press (n.d.).

Second, the trend of fertility decline and ageing is not reversible. Some expectations of easing the pressure of ageing in China assume that fertility levels will bounce back if the strict population policy is relaxed. Although the strict population policy played a dominant role in fertility declines in the 1980s, empirical studies find that the fertility decline since the 1990s has been dominated mostly by economic development rather than by population policy (Du 2005). If this is the case, the role of population policy in the determination of fertility has already been weak. In other words, changes in the population policy will not change the trend of ageing in the future.

A recent empirical study of fertility intentions supports this argument. In Jiangsu, Zheng (2011) investigates 5295 women of childbearing age who are allowed to have two children as per local population policy. She finds that, although on average women claim that they intend to have 1.5 children, the number in reality is only 1.09 on average. Figure 17.2 displays the results at various levels of fertility, ranging from 1.09 to 2, as per different definitions. If the results of this study were to be applied to the rest of China, one cannot expect that the country will change the trend of ageing by abolishing population policy. ${ }^{1}$

Finally, population ageing has taken place before China has become a rich country. As noted, 8.9 per cent of the total population in China was sixty-five or more years old in 2010. On average, the ratio for other developing countries is about 5 per cent. Considering that the process is not reversible, the only choice for China is to keep economic growth sustainable. According to Fogel (2007) and the Japan Centre for Economic Research (JECR 2007), the possibility that China will become a high-income country by 2020 is pretty high. If this prediction is true, China's ageing problem will not be significantly worse than in industrialised countries. According to the United Nations, people aged sixty-five or more years old will account for 12 per cent and 16 per cent of the total population in China by 2020 and 2030, respectively, compared with average shares for industrialised countries of 19 per cent and 23 per cent. 
Figure 17.2 Various fertility levels for women of childbearing age

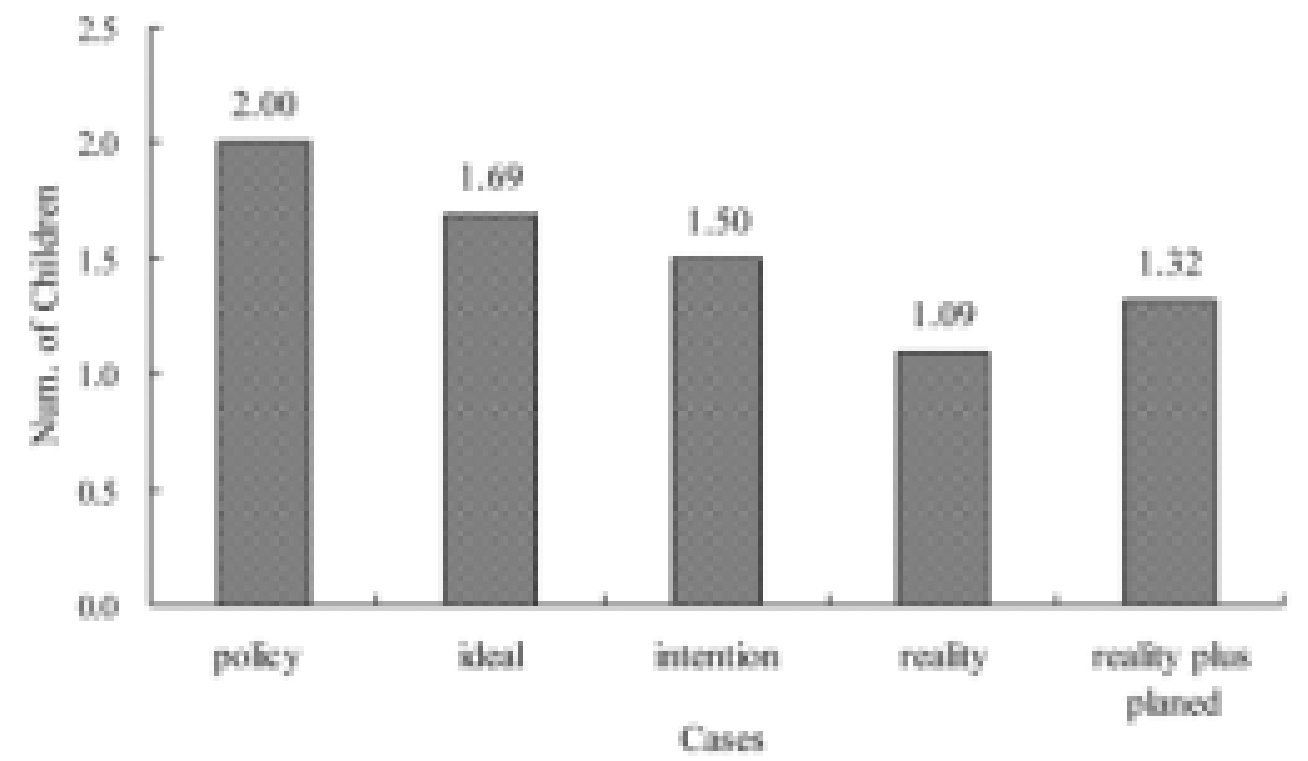

Source: Cited from Zheng (2011).

Therefore, the key strategy for China to cope with ageing is to maintain its pace of economic growth in the next decade - a period that is recognised as the 'Strategic Opportunity Period' by the Chinese Government. Responding to the effects of ageing on economic growth and its drivers (such as consumption) is of policy relevance now.

\section{Consumption patterns over the life cycle in urban China}

Due to the transitional features noted earlier, the determinants of household consumption are complicated in urban China. Naturally, the first factor that affects consumption patterns is income. Studies of industrialised countries that find declining consumption around retirement are based on the assumption that income at retirement is significantly less than work income, which encourages rational people to save in order to smooth their consumption over the life cycle. When observing the Chinese labour market, this assumption on income needs to be modified. As long as retired people are eligible for the urban pension system, their income in retirement-compared with many industrialised economies - is not significantly lower than their working income. According to the CULS, in 2010 average monthly earnings for male retirees with pensions were RMB1904-accounting for about 70 per cent of the population of working males. For females, the average retirement income was RMB1484 - accounting also for about 70 per cent of the population of working females. Furthermore, retired people have different education distributions to working people, with the latter having a higher educational attainment, on average. So, if we look at income 
comparisons by education group, it can be easily seen that retirees actually receive very generous pay, especially those in low-education groups. Table 17.2 gives the details of the comparison.

Table 17.2 Income comparison by education group: retired versus working

\begin{tabular}{|c|c|c|c|c|}
\hline & Primary school & $\begin{array}{l}\text { Junior high } \\
\text { school }\end{array}$ & $\begin{array}{l}\text { Senior high } \\
\text { school }\end{array}$ & $\begin{array}{l}\text { College and } \\
\text { above }\end{array}$ \\
\hline \multicolumn{5}{|l|}{ Male } \\
\hline Work income (RMB, a) & 1538 & 2049 & 2437 & 3486 \\
\hline Pension (RMB, b) & 1508 & 1751 & 1727 & 2687 \\
\hline $\mathrm{b} / \mathrm{a}$ & 0.98 & 0.85 & 0.71 & 0.77 \\
\hline \multicolumn{5}{|l|}{ Female } \\
\hline Work income (RMB, a) & 1405 & 1315 & 1848 & 2824 \\
\hline Pension (RMB, b) & 1211 & 1431 & 1524 & 2334 \\
\hline $\mathrm{b} / \mathrm{a}$ & 0.86 & 1.09 & 0.82 & 0.83 \\
\hline
\end{tabular}

Source: Authors' calculation using the survey data from CULS (CASS 2010).

Thanks to the generous pay for retirees, Chinese urban income and consumption patterns over the life cycle are thus different from those in industrialised economies. For example, Browning and Crossly (2001) find an inverted-U shape for consumption and income within the working life for a sample of UK couples. Limited as we are by data sources, it is not possible to observe the life-cycle effect in income and consumption strictly by cohort. We can, however, still see how the pattern of income and consumption changes with age in our data. The two panels of Figure 17.3 depict the changes of consumption and income with age, respectively. It seems that consumption declines as age increases through the workingage period, while it is stable after retirement. The pattern of income change over the life cycle is more complicated. In addition to an inverted-U shape within the working life, a slight increase is found around retirement. There are two possible explanations here. First, the official retirement age varies across groups of people - for example, males and females, and workers in different occupations. Second, early retirees might receive an increase in income when they qualify to withdraw benefits from their pension account.

As for the components of total consumption, the case in China differs from the findings in industrialised economies, too. According to the stylised facts summarised by Hurst (2008), the declines in expenditure around retirement are limited mostly to two types of consumption categories: work-related items (such as clothing and transportation expenditure) and food (both at home and away from home). When applied to the situation in urban China, we find a dissimilar pattern in food consumption although a justifiable explanation is still expected. As shown in the left-hand panel of Figure 17.4, food consumption displays a U-shape within working life and is slightly increased after retirement. 
Figure 17.3 Consumption and income with age increase
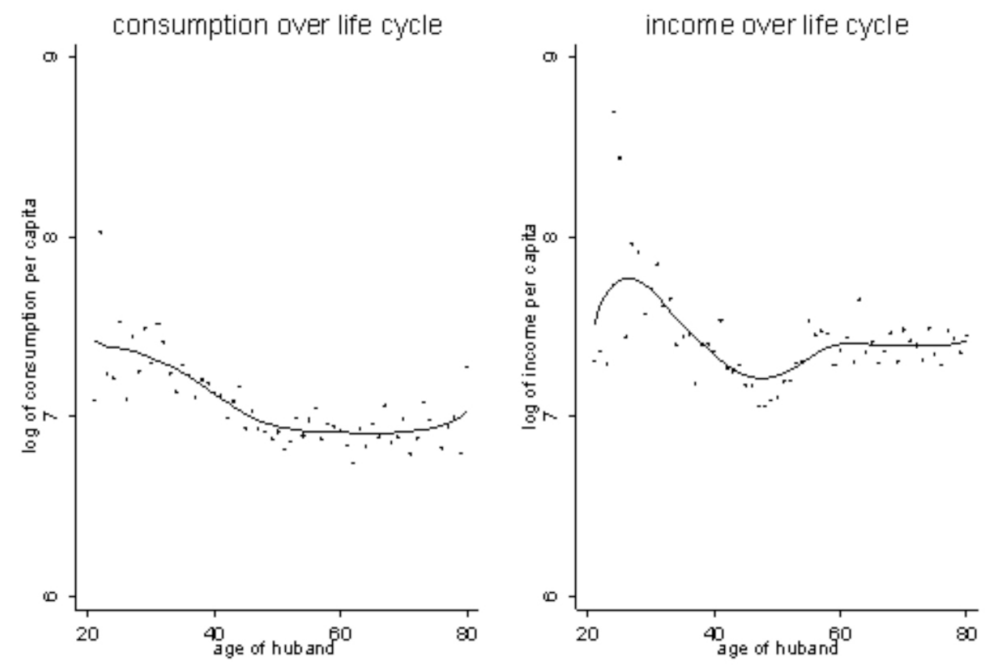

Source: Authors' calculations based on the survey data from CULS (CASS 2010).

Figure 17.4 Food and work-related consumption over the life cycle
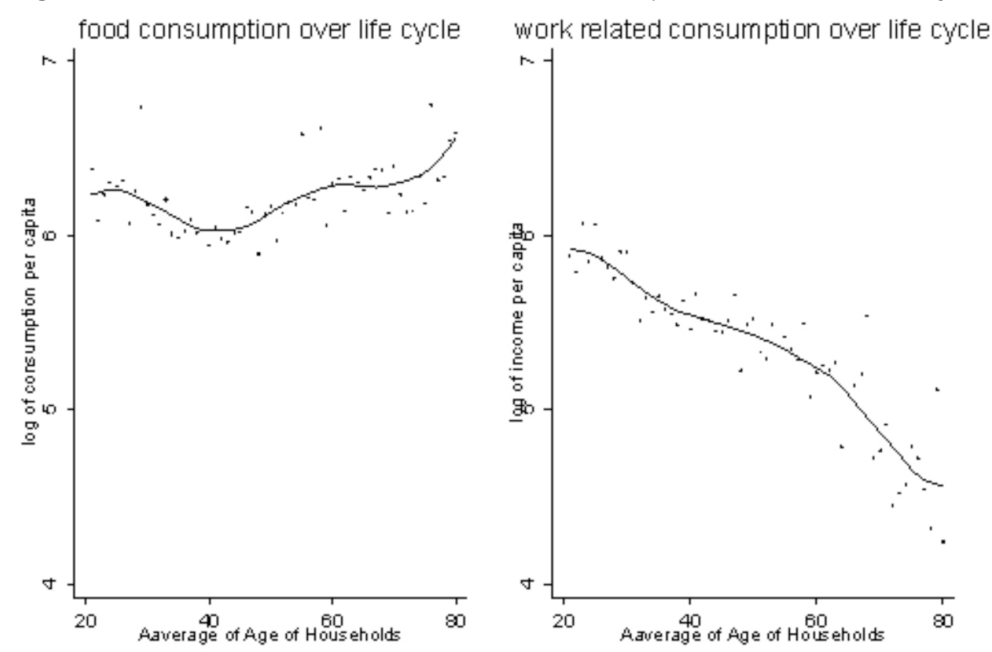

Source: Authors' calculations based on the survey data from CULS (CASS 2010).

The change in work-related consumption is quite obvious, as evidenced by the righthand panel of Figure 17.4, where a very negative slope of the curve is found. In particular, the slope is steeper after retirement.

The last two categories of household consumption worth mentioning here are expenditure on housing and out-of-pocket medical spending. As shown in the left-hand panel of Figure 17.5, although the dots are quite diversified, a general declining trend is found as age increases. The pattern of out-of-pocket health expenditure is not surprising because the elderly are in general not sufficiently covered by the social health insurance system. In addition, the magnitude of medical expenditure in some households is quite large. 
Figure 17.5 Housing and out-of-pocket medical spending
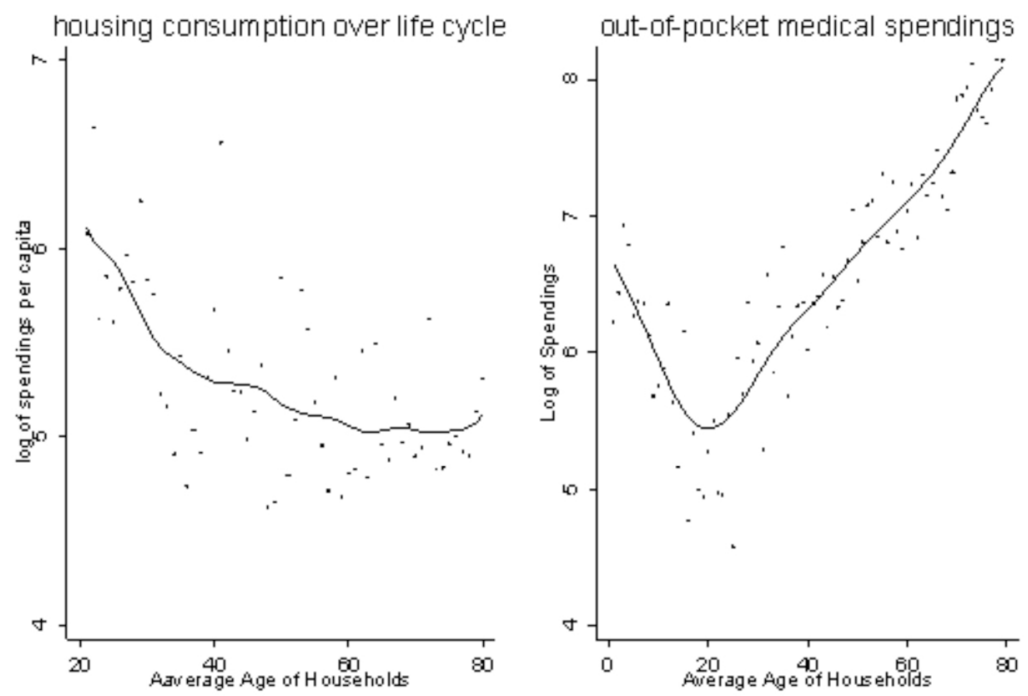

Source: Authors' calculations based on the survey data from CULS (CASS 2010).

To summarise the consumption pattern, Table 17.3 presents the composition of household consumption by age group. The table expresses the following features regarding the structure of consumption over the life cycle in urban China. First, compared with households of working age, aged households tend to reduce their expenditure on work-related items. Second, food consumption accounts for a large share in elderly households. Third, there is almost no difference in consumption shares on housing between the two groups. Finally, elderly households (defined as households with an average age of sixty-five or above) spend far more resources on medical care under the current healthcare system.

Table 17.3 Composition of household consumption in urban China (per cent)

\begin{tabular}{|l|r|r|r|r|r|r|c|}
\hline \multicolumn{1}{|c|}{ Age group } & Food & $\begin{array}{c}\text { Work } \\
\text { related }\end{array}$ & Housing & Service & Education & Health & Total \\
\hline Working-age average & 45.0 & 23.0 & 13.9 & 5.6 & 7.1 & 5.4 & 100.0 \\
\hline $20-$ & 42.7 & 20.9 & 22.0 & 9.5 & 0.7 & 4.2 & 100.0 \\
\hline $20 \sim 29$ & 41.2 & 25.6 & 18.2 & 5.8 & 6.4 & 2.9 & 100.0 \\
\hline $30 \sim 39$ & 42.0 & 23.1 & 12.5 & 5.2 & 13.0 & 4.4 & 100.0 \\
\hline $40 \sim 49$ & 45.3 & 24.2 & 13.2 & 5.3 & 5.7 & 6.2 & 100.0 \\
\hline $50 \sim 59$ & 51.6 & 19.2 & 13.8 & 6.1 & 1.7 & 7.5 & 100.0 \\
\hline Old-age average & 54.8 & 12.6 & 13.7 & 7.9 & 0.0 & 10.9 & 100.0 \\
\hline $60 \sim 69$ & 51.6 & 19.2 & 13.8 & 6.1 & 1.7 & 7.5 & 100.0 \\
\hline $70 \sim 79$ & 55.6 & 10.0 & 14.1 & 7.8 & 0.0 & 12.5 & 100.0 \\
\hline $80+$ & 49.4 & 9.0 & 13.9 & 11.3 & 0.0 & 16.4 & 100.0 \\
\hline All & 47.0 & 20.9 & 13.9 & 6.1 & 5.7 & 6.6 & 100.0 \\
\hline
\end{tabular}

Note: Work-related consumption is defined as expenditure on transportation, clothing, communications, culture and entertainment. Source: Authors' calculations based on the survey data from CULS (CASS 2010). 


\section{Empirical model and estimation results}

The impact of ageing on consumption has been widely considered by academics in China. Very few empirical studies based on micro-level data have been conducted, however, due to data limitations. In this section, we take advantage of the CULS data to examine empirically the effect of ageing on household consumption.

\section{Measuring income and consumption}

To a large extent, consumption patterns are determined by individual behaviour. When measuring income and consumption, some items are measured at the individual level. Some, however, are not separable among household members. We have information about expenditure on education and out-of-pocket health care by individuals, but the remaining expenditure is at the household level. For this reason, we aggregate individual consumption to the household level and observe the effect of relatively aged households on consumption rather than of individuals.

According to the CULS data, household incomes consist of working income, pension income, asset income, private transferred income, public transferred income, and other income. The survey also carefully investigates household consumption. The items of expenditure are regrouped as in Table 17.3, and Table 17.4 gives the descriptive statistics on income and expenditure.

Table 17.4 Descriptive statistics on income and expenditure

\begin{tabular}{|l|c|c|c|c|}
\hline & Mean & Std dev. & Min. & Max. \\
\hline Income per capita & 1753.9 & 1451.6 & -3263 & 22033 \\
\hline Working income & 1010.4 & 1228.4 & 0 & 18250 \\
\hline Pension income & 633.1 & 807.3 & 0 & 10000 \\
\hline Asset income & 96.5 & 607.0 & 0 & 12708 \\
\hline Private transfer & -4.3 & 397.8 & -4583 & 18333 \\
\hline Public transfer & 8.7 & 55.7 & 0 & 1389 \\
\hline Other income & 9.4 & 347.2 & 0 & 20833 \\
\hline Expenditure per capita & 1184 & 1283 & 0 & 70992 \\
\hline Food & 490.2 & 399.0 & 0 & 15000 \\
\hline Work-related items & 252.7 & 281.0 & 0 & 3150 \\
\hline Housing & 220.0 & 1002.8 & 0 & 68300 \\
\hline Service & 82.5 & 236.7 & 0 & 7572 \\
\hline Education & 65.6 & 161.8 & 0 & 3767 \\
\hline Health & 72.9 & 200.6 & 0 & 4167 \\
\hline Number of observations & 3573 & & & \\
\hline
\end{tabular}

Source: Authors' calculations based on the survey data from CULS (CASS 2010).

\section{Measuring population ageing}

As discussed earlier in this chapter, most expenditure and some income are inseparable among household members. Although at the aggregate level population ageing is measured by the share of elderly people in the total population, this is not a good measurement 
at the household level. In particular, we need to look at the effect of population ageing on household consumption rather than the consumption of individuals. Here, we measure the effect of population ageing by looking at the average ages of the households and define the households with average ages more than sixty-five as elderly households. Considering that elderly households could include some young members in this definition, we include some variables reflecting household compositions in the regression.

Based on the above definition, 15 per cent of sampled households are defined as elderly households in our sample.

\section{Model and estimation results}

The purpose of the empirical model is to look at the effects of population ageing on household consumption, including the effect on overall household consumption and its components. To capture the effect of ageing precisely, the core of the empirical strategy is to control the other factors that might also affect the consumption of urban households. Several types of household variables are included in the regression. The regression model is specified as follows: $\mathbf{Y}$ refers to the vector of income variables, $\mathbf{H}$ is a vector of household characteristic variables, and $\mathbf{S}$ stands for social insurance coverage (Equation 17.1).

\section{Equation 17.1}

$$
\mathrm{C}=\mathrm{Fa}+\mathrm{HH}+\mathrm{Sy}+\mathrm{E}
$$

First, income is the fundamental determinant of consumption. Not only a control variable, it is also used to capture the effect of income on consumption per se at different income levels. If the majority of income in a given household comes from the pension of an elderly family member, this member might have more power than others in making decisions on what will be consumed in the household. Therefore, we also add variables reflecting the structure of household incomes into the regression-for example, the share of pension income in total income, the share of work income in total income, and the share of asset income in total income.

Second, other household composition variables could affect the pattern of household consumption, too. The following variables are included in the regression: household size is to capture the scale economy of household consumption. The fraction of children of different age groups (zero $\sim$ six, seven $\sim$ five, and sixteen $\sim$ twenty-two) is also used to control their impacts on some types of expenditure, such as on education.

Finally, by adding the individual participation of social insurance, a household variable measuring access to social insurance is added. The impact of social insurance participation on current consumption could, however, be mixed. On the one hand, people with social insurance might have stable expectations of the future, which could encourage current consumption. On the other hand, expenditure on social insurance reduces income, which could have negative impacts on current consumption. City dummies in the regression are used to capture the regional factors that might affect household consumption. 
To observe the consumption pattern of households at different levels of consumption, simultaneous quantile regression is applied. Two variables are of interest here: household income per capita and the variable measurement of population ageing. We look at their effects on per capita household expenditure, work-related consumption, and healthcare expenditure. Only the two variables are presented in Table 17.5 for simplicity.

Table 17.5 Simultaneous quantile regression results

\begin{tabular}{|c|c|c|c|c|}
\hline & 20th & 40th & 60th & 80th \\
\hline \multicolumn{5}{|c|}{ Log of household expenditure per capita } \\
\hline \multirow[t]{2}{*}{ Log of household income per capita } & 0.346 & 0.333 & 0.354 & 0.382 \\
\hline & $(12.33)$ & $(14.58)$ & $(18.39)$ & $(15.39)$ \\
\hline \multirow[t]{2}{*}{ Old household } & -0.031 & 0.004 & 0.055 & 0.092 \\
\hline & $(-0.58)$ & $(0.11)$ & $(1.55)$ & $(2.11)$ \\
\hline Pseudo R2 & 0.239 & 0.236 & 0.220 & 0.196 \\
\hline Number of observations & & & & 3518 \\
\hline \multicolumn{5}{|c|}{ Log of work-related expenditure per capita } \\
\hline \multirow[t]{2}{*}{ Log of household income per capita } & 0.623 & 0.578 & 0.582 & 0.567 \\
\hline & $(9.89)$ & $(15.44)$ & $(11.48)$ & $(12.79)$ \\
\hline \multirow[t]{2}{*}{ Old household } & -0.600 & -0.605 & -0.558 & -0.435 \\
\hline & $(-4.76)$ & $(-6.30)$ & $(-7.66)$ & $(-4.86)$ \\
\hline Pseudo R2 & 0.246 & 0.240 & 0.222 & 0.196 \\
\hline Number of observations & & & & 3518 \\
\hline \multicolumn{5}{|c|}{ Log of out-of-pocket heath expenditure per capita } \\
\hline \multirow[t]{2}{*}{ Log of household income per capita } & 0.018 & 0.067 & 0.044 & -0.038 \\
\hline & $(0.77)$ & $(1.03)$ & $(0.71)$ & $(-0.51)$ \\
\hline \multirow[t]{2}{*}{ Old household } & 0.087 & 1.222 & 0.938 & 0.964 \\
\hline & $(0.25)$ & $(6.15)$ & $(6.45)$ & $(7.17)$ \\
\hline Pseudo R2 & 0.134 & 0.061 & 0.072 & 0.082 \\
\hline Number of observations & \multicolumn{4}{|l|}{3518} \\
\hline
\end{tabular}

Note: t-statistics are in parentheses. The other regressors include the share of working income in total income, the share of pension income in total income, the share of asset income in total income, household size, percentage of household members aged between zero and six, percentage of household members aged between seven and fifteen, percentage of household members aged between sixteen and twenty-two, average years of schooling of household members, average coverage of social insurance among household members, and city dummies.

Source: Authors' estimations based on the survey data from CULS (CASS 2010).

\section{Discussion of estimation results}

It seems that population ageing has not affected the total expenditure of urban households. After controlling for the other factors, the ageing variable is statistically significant only in the case of the wealthiest households, and the sign of the coefficient is positive. In the same equation, we found that the wealthier households tend to have a slightly higher elasticity of consumption with respect to income, as evidenced by the coefficients of the income variable in the regression. The magnitude of the elasticity is about $0.33 \sim 0.38$, which means that income growth in all urban households is supposed to have some kind of effect on increasing consumption. 
The results on total expenditure do not, however, capture the effects of changing consumption patterns that are driven by population ageing. Due to ageing, household expenditure on some items increases and declines on some others. That is why we see insignificant effects on total expenditure. In the second regression, at each percentile, the elderly households consume significantly less than the young households in work-related items. The marginal effect is bigger in poor households than rich in households.

Although the income variable is statistically insignificant in the regression on healthcare expenditure, ageing affects this expenditure significantly except in the poorest households. This implies that the households have to bear the healthcare costs under the current health insurance system and this item of expenditure could crowd out the other household consumption.

\section{Conclusions}

Taking advantage of recent urban household data, this chapter has analysed the changing consumption pattern in urban households with respect to population ageing. The empirical results indicate that aged households significantly reduce their expenditure on work-related items although the effect of this on overall expenditure seems limited. Meanwhile, aged households spend far more resources on health care compared with their young counterparts.

Two implications lie in the pattern of expenditure on health. First, due to population ageing, it is expected that overall expenditure on health care will increase, which could negatively affect economic growth. Second, the empirical results also imply that healthcare expenditure could crowd out household consumption on the other items. Although the coverage of social health insurance in urban China has improved in recent years, in some cases the actual benefit to the households reimbursed by the healthcare system is not enough to deal with the health shock they encounter.

In China - a middle-income country - the marginal propensity of consumption in urban households is still high. Given this, policies to promote household income growth might have a positive impact on consumption growth, too. Strengthening reforms relating to income distribution will be a useful tool to rebalance the economy to a consumption-led growth pattern. For example, policies aiming to enhance the share of labour income in GDP will have the effect of increasing individual incomes.

The ongoing process of population ageing in China will definitely increase expenditure on health care. Our empirical results indicate that, if the current healthcare system is not reformed effectively, in terms of coverage and efficiency, the out-of-pocket expenditure on health care will further crowd out other forms of household consumption, which might become an unfavourable factor for determining future economic growth in China. 


\section{Bibliography}

Banks, J., Blundell, R. and Tanner, S. 1998, 'Is there a retirement-savings puzzle?', American Economic Review, vol. 88, no. 4, pp. 769-88.

Bernheim, B., Skinner, J. and Weinberg, S. 1997, What accounts for the variation in retirement wealth among US households?, NBER Working Paper 6227, National Bureau of Economic Research, Cambridge, Mass.

Browning, M. and Crossley, T. F. 2001, 'The life-cycle model of consumption and saving', Journal of Economic Perspectives, vol. 15, no. 3 (Summer), pp. 3-22.

Browning, M. and Lusardi, A. 1996, 'Household saving: micro theories and micro facts', Journal of Economic Literature, vol. 34, no. 4, pp. 1797-855.

Chinese Academy of Social Sciences (CASS) 2010, The China Urban Labour Survey, Institute of Population and Labour Economics, Chinese Academy of Social Sciences, Beijing.

Du, Y. 2005, 'The formation of low fertility levels and its impacts on long run economic growth in China', World Economy, p. 12.

Fogel, R. W. 2007, Capitalism and democracy in 2040: forecasts and speculations, NBER Working Paper No. 13184, National Bureau of Economic Research, Cambridge, Mass.

Hurst, E. 2008, The retirement of a consumption puzzle, NBER Working Paper 13789 (February), National Bureau of Economic Research, Cambridge, Mass.

Japan Centre for Economic Research (JCER) 2007, Demographic Change and the Asian Economy, Long-term Forecast Team, Economic Research Department, Japan Centre for Economic Research, Tokyo.

Modigliani, F. and Brumberg, R. 1954, 'Utility analysis and the consumption function: an interpretation of the cross section data', in K. Kurihara (ed.), Post-Keynesian Economics, Rutgers University Press, New Brunswick, NJ, pp. 388-436.

National Bureau of Statistics (NBS) various years, China Statistical Yearbook, China Statistics Press, Beijing.

National Bureau of Statistics (NBS) 2011, The Statistical Communiqué on the Sixth Population Census in 2010 (No. 1), National Bureau of Statistics, Beijing, <www.stats.gov.cn>

Peking University Press n.d., Brief History of World Population, [In Chinese], Peking University Press, Beijing.

Zheng, Z. 2011, 'Childbearing intention and childbearing behavior: evidence from Jiangsu survey', Population Research, no. 2.

\section{Endnotes}

1. Of course, this is not a reason for keeping the current population policy unchanged. 